\title{
Efficacy of cerebrolysin on dentate gyrus of hippocampus after experimentally induced acute ischemic stroke in adult albino rats (Histological, immunohistochemical and biochemical study)
}

\section{Original Article}

\author{
Heba M. Abdel-Aziz', Samah M. Ahmed ${ }^{1}$, Maha Z. Mohammed ${ }^{I}$ and \\ Hanim M. Abdel-Nour ${ }^{2}$
}

${ }^{1}$ Department of Histology and Cell Biology, ${ }^{2}$ Department of Medical Biochemistry, Faculty of Medicine, Zagazig University

\begin{abstract}
Background: Acute ischemic stroke (AIS) is a brain medical disorder characterized by the sudden loss of blood circulation to an area of the brain, resulting in a loss of its neurologic function. Cerebrolysin is a mixture of neuropeptides and free amino acids.

Aim of the work: This study aimed to evaluate the role of cerebrolysin in ameliorating the histological,immunohistochemic al and biochemical harm in post ischemic stroke and also to assess its dose dependent effect.

Materials and Methods: Thirty adult male rats were divided into 3 equal groups; control, ischemic and post ischemic treated groups. After dissecting hippocampal dentate gyrus prepared sections were stained with hematoxylin and eosin, Er $\beta$ and calretinin proteins. Oxidative stress parameters, TNF $\alpha$, and HSP-70 assay. Also, Gh receptor gene expression and DNA fragmentation test were measured. Immunoperoxidase reactions for GFAPin astrocyte was estimated. Statistical analysis was conducted.

Results: Ischemia group showed decrease number of granule cells with small dark stained nuclei, areas of cell loss and numerous spindle shaped cells in the sub-granular zone. A faint positive immunoreaction for ER $\beta$ in nuclei of granular cells and negative reaction for calretinin was detected in granule cells. Antioxidant enzymes in the brain tissue as MDA,TNF $\alpha$ and HSP-70 were significantly elevated in ischemic group compared to control and post ischemic treated groups. Gh receptor gene were decreased, while Fragmentation index of DNA was significantly increased. Administration of $2.5 \mathrm{mg} /$ $\mathrm{kg}$ cerebrolysinshowed partial improvement, whereas, $5 \mathrm{mg} / \mathrm{kg}$ dose displayed more ameliorative effects. Increased GFAP immune-expression in the cytoplasm of astrocytes in ischemic group compared to control and post ischemic treated groups Conclusion: Cerebrolysin was effective in experimentally induced AIS (Acute ischemic stroke) in a dose-dependent manner as proved by improving the histological structure, immunohistochemical reactions and biochemical parameters of the dentate gyrus of hippocampus in adult male albino rats.
\end{abstract}

Received: 07 July 2018, Accepted: 27 August 2018

Key Words: Cerebrolysin, ghrelin, histology, ischemia, oxidative stress.

Corresponding Author: Heba M. Abdel-Aziz, Lecturer of Histology and Cell Biology, Faculty of Medicine, Zagazig University, Zagazig, Egypt, Tel.: +20 1281547665, E-mail: hebaeraky37@gmail.com

ISSN: $1110-0559$, Vol. 42, No. 1

\section{INTRODUCTION}

Acute ischaemic stroke (AIS) is a major cause of death and disability all over the world ${ }^{[1]}$. It is the third cause of death, after heart diseases and cancer in major industrialized countries ${ }^{[2]}$. The cerebral ischemia results from a temporary or permanent reduction of cerebral blood flow that may lead to both acute or chronic dysfunctions in the central nervous system $(\mathrm{CNS})^{[3]}$. Acute cerebral ischaemia caused mostly by thrombosis in cerebral vessels or embolism from large blood vessels or even from systemic hypo perfusion ${ }^{[4]}$. Chronic cerebral hypoperfusion is a major cause of dementia and Alzheimer's disease and can a result from hypertension, diabetes, generalized atherosclerosis and smoking ${ }^{[5]}$. Throughout cerebral ischemia, tissue damage results from diverse mechanisms with central involvement of inflammation, oxidative stress, free radicals overproduction, resulting in an activation of transcription factors and alteration in gene expression ${ }^{[6,7 \& 8]}$. Additionally, a highly pleiotropic inflammatory cytokines as TNF- $\alpha$ expected to augment or discourage cellular survival through activation of receptor-mediated signal transduction ${ }^{[9]}$.

The hippocampal system consists of the dentate gyrus, cornuammonis (CA) fields and the subiculum.Dentate gyrus has three layers; molecular, granule cell and polymorphic layers. The sub-granular zone (SGZ) is one of the stemcell-containing niches in the adult mammalian brain and present at the interface between the hilus and the granular 
cell layer ${ }^{[10]}$. It is estimated that approximately 100 to 150 neurons are generated per day in SGZ of adult rodents. The milieu environment of it allows neuronal stem cell (NSC) proliferation and promoting the differentiation of dentate granule neurons. Adult-born dentate granule neurons pass through several consecutive developmental stages before they become functionally integrated into the hippocampal circuitry ${ }^{[11]}$. Radial glia-like cells (RGLs, Type 1 or B-cell) express nestin and GFAP and have prominent radial processes are thought to represent the NSC population and can generate intermediate progenitor cells (IPCs, type 2 cell or D- cells) that proliferate at a high rate ${ }^{[12]}$. These type 2 cells can give rise to neuroblasts (type 3 ) that subsequently differentiate into mature dentate granule neurons. Newly born neurons are located at the border of the subgranular zone-granular cell layer. When these neurons mature, they become positive for NeuN and calbindin ${ }^{[13]}$.

Estrogen regulates the synaptic plasticity and physiology of the hippocampus. It is demonstrate that its on hippocampal are mediated through $\mathrm{ER} \beta^{[14]}$. Calretinin is a calcium-bindig protein which was shown to be present in many brain regions ${ }^{[15]}$. Regulation of calcium homeostasis may be a key in the protection of the brain from injury ${ }^{[16]}$. Ghrelin, a gastrointestinal peptide with a major role in regulating feeding and metabolism. It has recently been investigated for its neuroprotective effects and useful therapeutic role in protecting the brain against injury ${ }^{[17]}$.

Amelioration of cerebral ischemia injury is one of the major problems of experimental medicine and biology ${ }^{[18]}$. Since approval by the FDA in 1996, intravenous administration of recombinant tissue plasminogen activator (rtPA) which dissolves the obstructive clot remains the only treatment for patients within 4.5 hours of stroke onset. However, only a small percentage of patients with ischaemic stroke are eligible for rtPA treatment, due to its narrow therapeutic window and the risk of brain hemorrhage ${ }^{[19,20]}$

Cerebrolysin is a mixture of an amino acid and peptide $^{[21]}$ that successfully has been used to support synaptic growth in the treatment of Alzheimer's disease ${ }^{[22]}$, traumatic brain injury and neurodevelopmental disorders, including schizophrenia ${ }^{[23]}$. Recent studies report that it reduces the central and peripheral neuropathy secondary to chronic hyperglycemia induced by streptozotocin in mice and rats ${ }^{[24]}$.

Recent data from a large scale randomized clinical trial showed that cerebrolysin can be safely administered to stroke patients with a trend towards improvement in the patients with severe stroke ${ }^{[25]}$. In another study ${ }^{[26]}$, the authors mentioned contradictory results because they did not obtain a beneficial effect of the drug in similar cases. Therefore, the purpose of this study was to investigate theeffectivenessof cerebrolysinin improving the histological, immunohistochemical and the biochemical changes of the dentate gyrus of hippocampus in experimentally induced cerebral ischemia in adult male albino rats and to explore whether this effect is changed with varying doses (dose-dependent response) or not.

\section{MATERIALS AND METHODS}

\section{Animals}

Thirty healthy adult male albino rats (3-5 months) weighing 180-200 g were used in this study. They were purchased from the centre of experimental animals, Faculty of Veterinary medicine, Zagazig University. They were housed in the animal house of faculty of medicine, Zagazig University under controlled laboratory conditions at room temperature $\left(20 \pm 2^{\circ} \mathrm{C}\right)$. They were fed a standard balanced diet and allowed water ad libitumThey were adaptedtolaboratory environments one week before initiation of the experiments ${ }^{[27]}$.

\section{Chemicals}

Cerebrolysin: was purchased from Sigma-Aldrich, Steinem, Germany Chemical Company. Cerebrolysin(vial) was given through dilution in a standard solution (physiological saline solution) infusedintraperitonial slowly over approximately 20 to 60 minutes daily in the morning (between 10:00 and 12:00 am) for a period of 10 days.

\section{Induction of acute cerebral ischemia}

According toCarvalho et al. ${ }^{[28]}$ after one week of acclimatization, the rats were anesthetized by halothane inhalation, fixed in a supine position and intubated with an oro-tracheal cannula. A midline incision was made in the neck, after that the incision was extended $1 \mathrm{~cm}$ to the right then both common carotid arteries and the right common jugular vein were exposed carefully by blunt dissection. The distal end of the common jugular vein was ligated cranially and sectioned for the retrograde introduction of a $2.5 \mathrm{~cm}$ long obstructive $4-0$ mononylon suture with one end thickened with silicone over an extension of $5 \mathrm{~mm}$. The suture was introduced until to reach the common carotid artery and then cranially progressed through the internal carotid artery until to reach and ligate the middle carotid artery to make acute cerebral ischaemia. Then the muscles and the skin of the neck were sutured separately.

To prevent wound damage from other animals, they were caged separately for post-surgical care. According to Al-Bazii ${ }^{[29]}$, the surgical wound of the operated rats was cleaned with povidone iodine twice a day for 5 days. Rats in the sham group received the fake operation.

\section{Experiment design}

\section{Three groups of albino rats were assigned}

Group I (Control group): included ten rats, and further subdivided into two equal subgroups (5 rats each):

Subgroup Ia (Negative control group): rats were kept without any treatment.

Subgroup Ib (Positive control group; sham operated): 
Rats were submitted to the same surgical procedure (as group II) without ligation of middle carotid artery ${ }^{[30]}$.

Group II (ischaemic group): ten ratswere subjectedto acute cerebral ischaemia through middle carotid artery occlusion $^{[28]}$.

Group III (post ischaemic treated group): ten animals were equally subdivided into two groups (5 rats each)

Subgroup IIIa: rats were administered $2.5 \mathrm{ml} / \mathrm{kg}$ of cerebrolysininfusedintraperitonially after $4 \mathrm{~h}$ of onset of cerebral ischaemia daily for 10 days ${ }^{[31]}$.

Subgroup IIIb: rats were administered $5 \mathrm{ml} / \mathrm{kg}$ of cerebrolysininfusedintraperitonially after $4 \mathrm{~h}$ of onset of cerebral ischaemia daily for 10 days ${ }^{[31]}$.

At the end of the experiment, all rats then were injected intraperitoneally with $25 \mathrm{mg} / \mathrm{kg}$ sodium thiopental. They were put in a supine position on a dissection table, then the chest wall was opened, they were perfused transcardially through the left ventriclewith $10 \%$ formolsaline. The descending aorta was ligated before perfusion and the right atrium was opened once perfusion had started and when the venous return from the right atrium became clear, the perfusion was stopped ${ }^{[32 \& 33]}$. Successfully perfused brain was dissected out through an incision made in the posterior of the neck. The skull was removed carefully to expose the brain. Left and right hemispheres of the brain were dissected out and kept in $10 \%$ formalin at room temperature ${ }^{[34]}$. Brain specimens were prepared for histological, immunohistochemical and biochemicalstudies.

\section{Methods}

\section{Histological study}

Brain tissue was placed in 10\% formalin solution, then embedded in paraffin for histological analysis and. Paraffin sectionsof 4-5 $\mu \mathrm{m}$ thickness were prepared to be stained by Haematoxylin and Eosin $(\mathrm{H} \& \mathrm{E})^{[35]}$.

\section{Immunohistochemical study}

Immunohistochemical detection of GFAP, $\operatorname{Er} \beta$, and calretinin proteins was carried out using streptavidinbiotin complex immunoperoxidase system. Serialparaffin sectionswere deparaffinized on charged slides, then, incubated in $0.1 \%$ hydrogen peroxide for $30 \mathrm{~min}$ (to block theendogenous peroxidase) and finally incubated with the primary antibody ${ }^{[35]}$.

\section{Detection of GFAP}

Sections were incubated with mouse anti-GFAP antibody (Cat. No. MS- 280- R7, Lab Vision Corporation, Fremont, USA) diluted in 1:100 in phosphate buffered saline in Lab Vision antibody diluent (Cat. TA- 125- UD). The primary antibody was incubated for 2 hours at room temperature, then washes with phosphate buffer solution (PBS). The primary antibodies were detected by incubation with biotinylated goat anti-mouse IgG in a concentration of 1:500 diluted in phosphate buffered saline for 1 hour
(Zymed Laboratories; South San Francisco, CA, USA) for 30 min at room temperature ${ }^{[36]}$.

\section{ERß expression}

Sections were incubated rabbit polyclonal IgG anti-rat Erßantibody (Cat. No. PA1-311, Thermo Fisher Scientific, Rockford, USA) at 1-2 $\mu \mathrm{g} / \mathrm{mL}$ diluted in PBS for 2 hours at room temperature. After several washes with PBS, primary antibodies were detected by incubation with biotinylated anti-rabbit antibodies diluted in phosphate buffered saline (versal kits, Zymed laboratories) for 1 hour at room ${ }^{[37]}$.

\section{Calretinin protein expression}

Sections were incubated with calretinin rabbit polyclonal antibody (Catalog ID:GTX103261; Lifespan Biosciences, Inc., Seattle, WA, USA; at a dilution of 1:100 MS- 280- R7, Lab Vision Corporation, Fremont, USA) diluted in phosphate buffered saline 1:100 in Lab Vision antibody diluents (Cat. TA- 125- UD) for 2 hours at room temperature. After several washes with PBS, primary antibodies were detected by incubation with biotinylated goat anti-mouse IgG (Zymed Laboratories; South San Francisco, CA, USA) for 1 hour at room ${ }^{[37]}$.

All sections were incubated with the streptavidinbiotin peroxidase complex for $30 \mathrm{~min}$ at room temperature. After washing with PBS, reactions were visualized with 3', diaminobenzidinetetrahydrochloride (DAB - SigmaAldrich Chemical Co., St. Louis, USA) used as chromogen to visualize antibody binding. The sections were counterstained with Mayer's hematoxylin, dehydrated and mounted by DPX. Negativecontrols were processed according to the same protocol, except for the use of the primary antibody ${ }^{[37]}$.

\section{Biochemical study}

For biochemical determinations a supernatant obtained from brain tissues were performed as the following. The tissue sample (one gram of tissue) was rinsed in cold physiological saline and homogenized with tissue homogenizer. The homogenate was centrifuged at 4000 RPM for $15 \mathrm{~min}$ at $4^{\circ} \mathrm{C}$ for $30 \mathrm{~min}$, and the supernatant was stored on ice was kept at $-2^{\circ} \mathrm{C}$ for analysis ${ }^{[38]}$.

\section{Oxidative stress parameters}

These parametersinclude malondialdehyde (MDA) as an index for lipid peroxidation (LP), antioxidant enzymes as Catalase (CAT) and reduced glutathione (GSH). The amount of malondialdehyde (MDA) in tissue homogenate was determined according to Ohkawa et al. ${ }^{[39]}$ based on the reaction with thiobarbituric acid. SOD activity was estimated based on inhibiting pyrogallol auto-oxidation by it as described by Marklund ${ }^{[40]}$. The inhibition rate is directly proportional to the activity of SOD in tissue. Catalase (CAT) activity was determined according to Clairborne ${ }^{[41]}$ based on the decomposition of hydrogen peroxide by catalase enzyme. Reduced glutathione (GSH) concentration was assayed according to Ellman ${ }^{[42]}$. 
The spectrophotometric detection at $\mathrm{O}=532$ and 600 $\mathrm{nm}$ follows a reaction in an acid environment and incubation at $95^{\circ} \mathrm{C}$. All metabolites were purchased from (Biodiagnostic, Giza, Egypt).

\section{Tumor necrosis factor alpha $(\mathrm{TNF}-\alpha)$ assay}

TNF- $\alpha$ levels were determined by Enzyme-LinkedImmuno-Sorbent-Assay (ELISA) using rat TNF- $\alpha$ kits were procured from Sigma-Aldrich Saint Louis, MO, USA. Homogenates of brain tissue groups were made and centrifuged at $4^{\circ} \mathrm{C}$. The supernatants were collected, and used to detect the levels of TNF- $\alpha^{[43]}$.

\section{Measurement of HSP-70}

HSP-70 protein expression in brain tissue was detected using a commercial HSP70 ELISA kit (StressgenBioreagents, Ann Arbor, MI). The protein was isolated from brain tissue homogenate by using protein extraction reagent. According to the assay proceduresupplemented with the kit, HSP-70 standards and samples were added to the HSP-70 immunoassay plate, incubated and washed, then anti-HSP-70 biotin conjugate was added, incubated and washed, finally avidin-HRP conjugate was added, incubated and washed. The colour was developed with 3, 3', 5, 5' tetramethylbenzidine. We measured its absorbance at $450 \mathrm{~nm}$. HSP70 in the samples was calculated Tissue total protein concentration was also measured with Coomassie blue method (assay kit was purchased from Nanjing Jiancheng Bioengineering Institute, Nanjing, China) ${ }^{[43]}$.

Gene expression of Gh-R "Ghrelin receptor gene":(Assayed in brain tissue by Real-time RTPCR)

Samples of brain tissue were dissected immediately and frozen in liquid nitrogen. Total-RNA was extracted from tissue samples using Trizol reagent (Invitrogen) according to standard protocol as described by Brinkhof et $a l^{[44]}$. The standard amount of total RNA (500 ng) was used to synthesize the first strand cDNA (High Capacity RNA-to-cDNA kit, Applied Biosystems, Foster City, CA). RT-PCR amplification mixtures $(25 \mu \mathrm{l})$ contained $1 \mu 1$ template cDNA, SYBER Green master mix buffer (Quanti-Tect, Qiagen, Hilden) and 400nM (10 pmol/ reaction) forward and reverse primer. Reactions were run on step one plus Real-Time PCR detector (Applied Biosystems). The results were analyzed by SDS software vs. 2.3 (Applied Biosystems). The expression of genes of interest was normalized to the housekeeper gene beta-actin and calculated using AA Ct method ${ }^{[44]}$. Sequence of the primers used for real-time PCR. Gene Primer sequence:

Ghrelin receptor gene Forward: 5'-CAAGAATGGCGACCGTGGTGA-3' Reverse: 5'GGTGTGACTCGTGCAGCCATC-3'ß. actin Forward: 5'-ATCATGTTTGAGACCTTCAACACC Reverse:5'TAGCTCTTCTCCAGGGAGG-3'[45].

DNA fragmentation test for apoptosis
Using DNA extraction kit and gel electrophoresis: DNA was extracted using genomic DNA extraction kit (TIANGEN, Beijing, china). Qualitative analysis of DNA fragmentation was done by submarine Gel Electrophoresis system (Pharmacia Biotech by SEMKO AB, Sweden) and submarine chamber (Maxicell, EC360, M-E-C apparatus co. stPetersuburg, FL). The gel image was photographed under ultraviolet trans-illumination (Heralab $\mathrm{GmbH}$ laborgerate trans-illuminator, Germany) $)^{[46]}$.

\section{Histo-morphometric analysis}

The image analyzer computer system Leica Qwin 500 (Leica Ltd, Cambridge, UK) at the Image Analyzing Unit of Pathology Department, Faculty of Dentistry, Cairo University, Egypt, was used to evaluate the astrocyte number and the area percent of GFAP, $\operatorname{Er} \beta$ and calretinin protein by the interactive measure menu. The measuring frame of a standard area equal to $118476.6 \mathrm{~mm}^{2}$ was chosen so that the brown positive immune reaction could be seen and masked to be measured. Ten readings from five non-overlapping sections from each rat of all groups were examined.

\section{Statistical analysis}

All data were expressed as mean \pm SD. Statistical analysis was performed using the Statistical Package for the Social Sciences (SPSS) software, version 13.00 (Chicago, Illinois, USA). Statistical significance was determined by one-way analysis of variance for differences between the means of different groups. Further analysis was carried out using the post-hoc test to compare the parameters between the different groups with each other. Probability of P less than 0.05 was considered statistically significant.

\section{RESULTS}

\section{Histological results}

H\&E stained sections of the control hippocampus showed parts of the CornuAmmonis (CA) as CA1, CA2, $\mathrm{CA} 3 \& \mathrm{CA} 4$ regions. Dentate gyrus was a $\mathrm{C}$ shaped structure enclosing CA4 (Fig. 1a). Dentate gyrus was formed of three layers; molecular, granule cell and polymorphic layers. The molecular layer was a relative cell-free layer containing neural cells and blood vessels. The granule cell layer contained rounded granule cells with vesicular nuclei. Spindleshaped cells were detected in the sub-granular zone(SGZ). Different types of cells as astrocytes were noticed in the polymorphic layer (Fig. 1b). Examination of H\&Estained sections of the ischaemia group showed small dark stained nuclei and areas of cell loss in the granule cell layer. Numerous spindle shaped cells were noticed in SGZ. The molecular and polymorphic layers revealed numerous astrocytes (Fig.1c).Sections in the dentate gyrus of subgroup IIIa revealed some granule cells with rounded vesicular nuclei, however others had small dark nuclei. The molecular layer contained astrocytes and blood capillaries. The polymorphic layer showed some vacuolations in the neuropil (Fig. 1d). H\&E stained sections of subgroup IIIb dentate gyrus showed granule cells with rounded and 
vesicular nuclei. Small spindle and rounded shaped cells were detected in SGZ. Molecular and polymorphic layers contained astrocytes (Fig. 1e).

\section{Immunohistochemical results}

Immunohistochemical reaction for GFAP in sections of the dentate gyrus of the hippocampus of the control group showed positive cytoplasmic reaction in the body and processes of the astrocytes that was less noticed in the granule cell layer (Fig. 2a).In the ischaemia group, strong positive cytoplasmic reaction for GFAP in the body and processes of astrocytes in the three layers of dentate gyrus (Fig. 2b). Immunohistochemical results for GFAP-stained sections of subgroup IIIa revealed positive cytoplasmic reaction in astrocytes that was moderate in the granule cell layer (Fig. 2c). GFAP-stained sections for subgroup IIIb revealed positive expression for GFAP in astrocytesthat was less noticed in the granule cell layer(Fig. 2d).

Immunohistochemical reaction for ER $\beta$ in sections of the dentate gyrus of the control group revealed a strong positive nuclear reaction of granule cells (Fig. 3a). Faint positive immunoreaction for ERßin some nuclei of granular cells of the ischaemia group (Fig. 3b). Immunohistochemical reaction for ER $\beta$ stained sections of subgroup IIIa revealed a strong positive nuclear reaction in most granule cells (Fig. 3c). ER $\beta$ immunoreaction in sections of the subgroup IIIb revealed a strong positive nuclear expression of granular cells (Fig. 3d).

Immunohistochemical reaction for calretinin in the dentate gyrus of the control group revealed strong positive reaction in the cytoplasm and processes of granule cells (Fig. 4a). Negative reaction for calretinin immunoreaction was detected in granule cells of the ischaemia group (Fig. 4b). Immunohistochemical results for calretinin stained sections of subgroup IIIa revealed strong positive reaction in most granule cells (Fig. 4c). Calretinin immunoreaction in sections of subgroup IIIb revealed strong positive expression in granule cells (Fig. 4d).

\section{Biochemical results}

\section{Oxidative stress parameters}

Assessment of the activities of lipid peroxidation revealed a significant increase of MDA in the ischaemicgroup as compared to the control group and post ischaemic treated group IIIa and IIIb.Furthermore, there was a non-significant decrease of MDAin post ischaemic treated group IIIb compared with the control group (Table 1). A significant decrease of GSH and CAT levels in the ischaemicgroup as compared to the control group and post ischemic treated group IIIa and IIIb. There was a nonsignificant difference between the control group and post ischaemictreatedgroupIIIb (Table1).

\section{TNF- $\alpha$ and HSP-70 assay and Ghrelin receptors $m R N A$ (Gh receptor) expression}

Assessment of brain tissue TNF- $\alpha$ and HSP-70revealed a significant increase in the ischaemicgroup when compared with the control group, post ischaemic treated group IIIa and IIIb. There was a non-significant difference between the control group and subgroupIIIb(Table2).Ghrelin receptor gene expressionshowed a significant decrease in the ischaemicgroup when compared with the control, post ischaemic treated group IIIa and IIIb. Furthermore, there was a non-significant difference between the control groupand post ischemic treated group IIIb (Table2).

\section{DNA fragmentation test for apoptosis}

DNA fragmentation was significantly observed in Lane 1 which representedthe ischemic group, Lane 2 represented the control group, Lane 3,4 represent post ischemic treated groups (IIIa) and (IIIb) respectively, showed regression of DNA shearing especially with post ischaemic treated group (IIIb) that was treated with high dose of cerebrolysin (Fig. A).

\section{Histomorphometric and statistical results}

Statistically significant increase in the mean number of astrocytes was noticed in the ischaemia group as compared to the control groupand subgroup IIIa and III b. No statistically significant difference was seen in the control group as compared to subgroups III b (Table 3 ).

Statistically significant increase in the mean area percent of GFAP immunoreaction was noticed in Group II as compared to the control group and subgroups IIIa and b. No statistically significant difference was seen in the control group as compared to subgroup III b (Table 3).

Statistically significant decrease in the mean area percent of ER $\beta$ immunoreaction was noticed in Group II as compared to Group I, subgroup IIIa, and b. No statistically significant difference was detected between Group I as compared to subgroup III b (Table 3).

Statistically significant decrease in the mean area percent of calretinin immunoreaction was noticed in Group II as compared to Group I, subgroups IIIa and b. No statistically significant difference was seen in Group I as compared to subgroup III b (Table 3 ). 

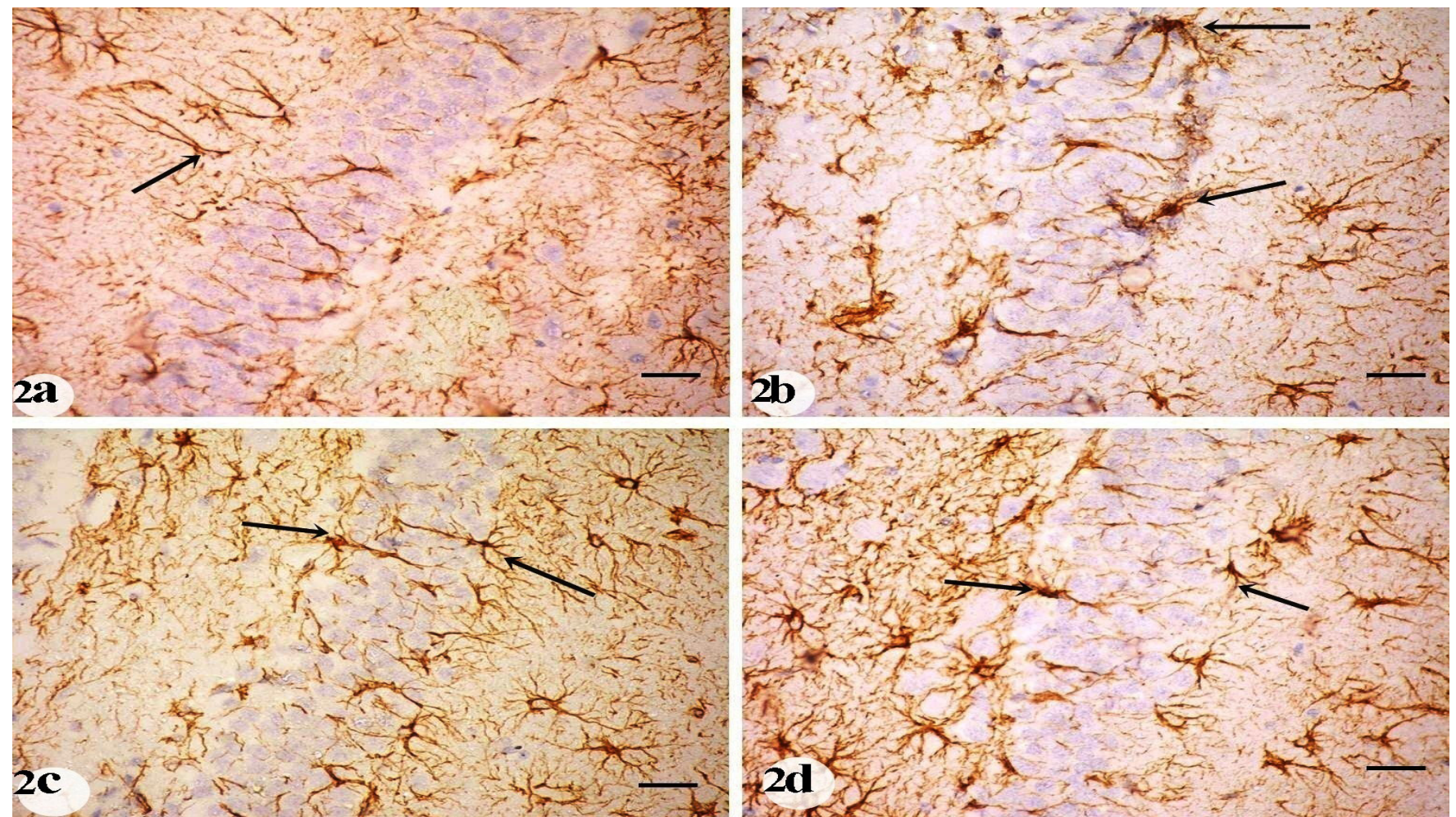

Fig. 2a: A photomicrograph of immunohistochemical reaction for GFAP in sections of the control dentate gyrus showing strong positive cytoplasmic reaction in the body and processes of astrocytes (arrow) that is less noticed in the granule cell layer.

2b: A photomicrograph of immunohistochemical reaction for GFAP in sections of the dentate gyrus of the ischemia group showing strong positive cytoplasmic reaction in the body and processes of astrocytes (arrow) in the three layers of dentate gyrus.

2c: Immunohistochemical results for GFAP stained sections of subgroup IIIa reveals strong positive cytoplasmic reaction in astrocytes (arrow) that is moderately detected in the granule cell layer.

2d: GFAP stained sections for subgroup IIIb reveals strong positive expression of GFAP in astrocytes (arrow) that is less noticed in the granule cell layer. (Immunoperoxidase technique for GFAP $\times 400$, scale bar $20 \mu \mathrm{m}$ )
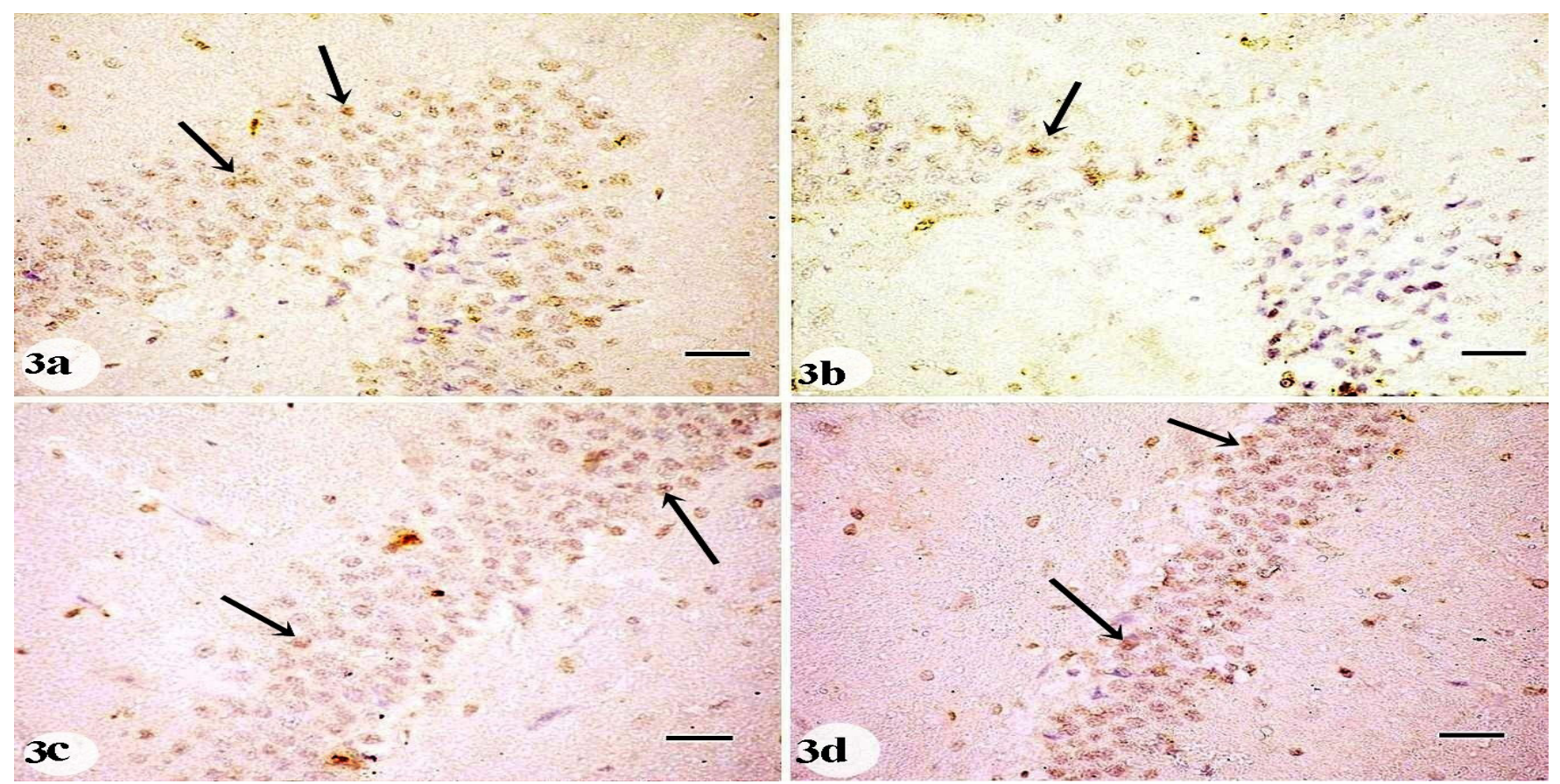

Fig. 3a: Immunohistochemical reaction for ER $\beta$ in sections of the dentate gyrus of the control group reveals strong positive nuclear reaction of granule cells (arrow).

3b: Faint positive immunoreaction for ER $\beta$ in some nuclei of granule cells (arrow) of the ischemia group.

3c: Immunohistochemical reaction for ER $\beta$ stained sections of subgroup IIIa reveals strong positive nuclear reaction (arrow) in most of granule cells.

3d: ER $\beta$ immunoreaction in sections of the subgroup IIIb reveals strong positive nuclear expression (arrow) of granule cells.

(Immunoperoxidase technique for ER $\beta, \times 400$, scale bar $20 \mu \mathrm{m}$ ) 

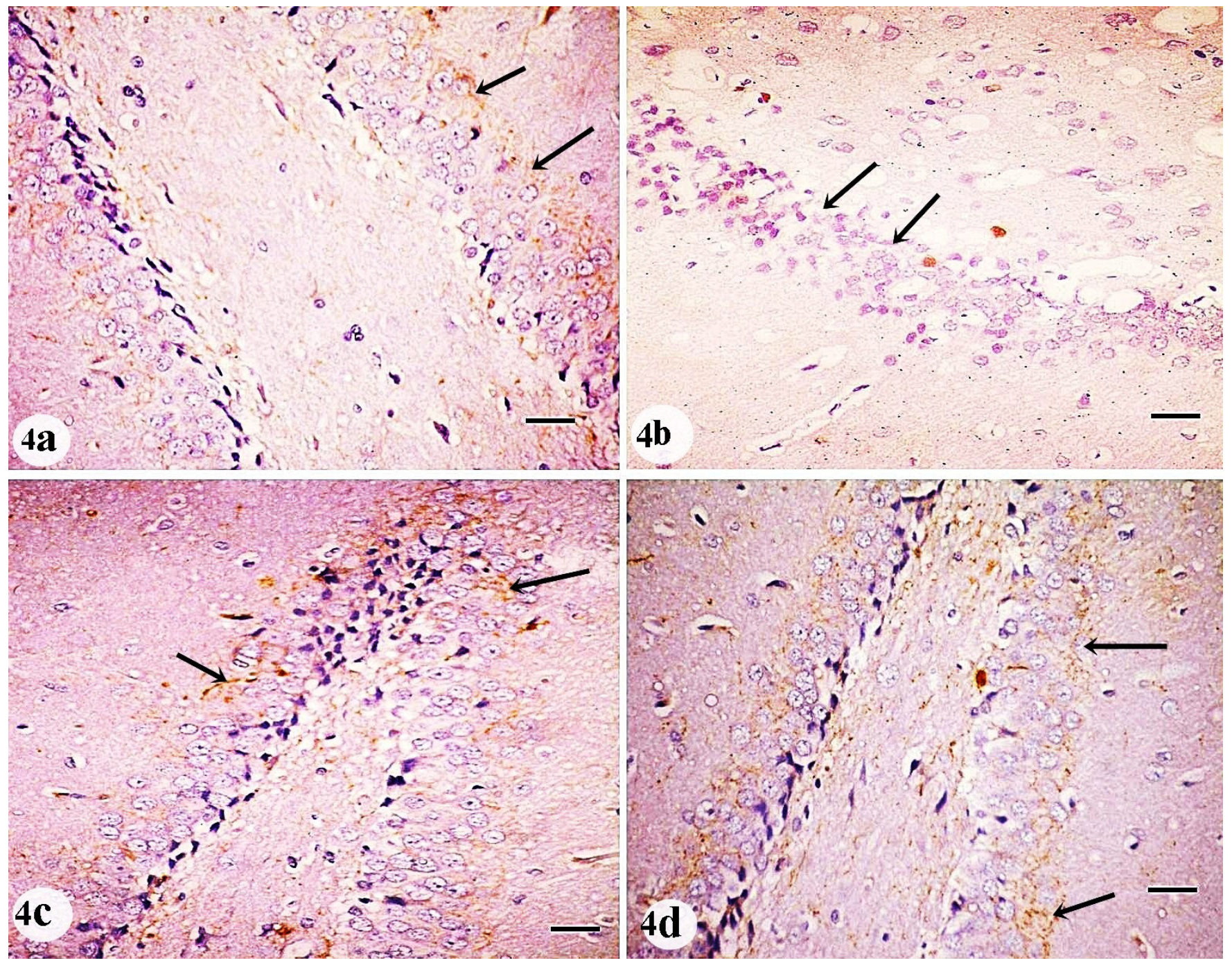

Fig. 4a: Immunohistochemical reaction for calretinin in the dentate gyrus of the control group showing strong positive reaction (arrow) in the cytoplasm and processes of neuronal cells.

4b: Negative reaction for calretinin immunoreaction is detected in neuronal cells (arrow) of the ischemia group.

4c: Immunohistochemical results for calretinin stained sections of subgroup IIIa showing strong positive reaction in most neuronal cells (arrow).

4d: Calretinin immunoreaction in sections of subgroup IIIb showing strong positive expression in neuronal cells (arrow).

(Immunoperoxidase technique for calretinin $\times 400$, scale bar $20 \mu \mathrm{m}$ )

Table 1: Oxidative and antioxidant biomarkers levels in brain tissue values expressed as mean $\pm \mathrm{SD}$

\begin{tabular}{|c|c|c|c|c|c|c|}
\hline \multirow{2}{*}{ Parameters Groups } & Control (I) & Ischemia (II) & Post ischemic IIIa & Post ischemic IIIb & \multirow{2}{*}{$\mathrm{F}$} & \multirow{2}{*}{ P. value } \\
\hline & Mean \pm SD & Mean $\pm \mathrm{SD}$ & Mean \pm SD & Mean \pm SD & & \\
\hline MDA (nmol/g tissue) & $45.3 \pm 1.3^{\# \$}$ & $81.4 \pm 2^{* @ @ ~}$ & $49.3 \pm 1.3^{* \# @(@) ~}$ & $42.5 \pm 4.5^{\text {\# }}$ & 238.372 & $<0.001^{* *}$ \\
\hline GSH (nmol/ tissue) & $2.1 \pm 0.1^{\# \mathrm{~S}}$ & $0.9 \pm 0.02^{*} @$ & $2.6 \pm 0.1^{* * @ @ ~}$ & $2.2 \pm 0.1$ \#\$ & 213.706 & $<0.001^{* *}$ \\
\hline CAT (u/g tissue) & $8.7 \pm 0.6^{\# \mathrm{~S}}$ & $5.4 \pm 0.8^{*} @$ & $10.7 \pm 0.5^{* * @}$ & $9.3 \pm 0.9^{\text {\#S }}$ & 48.961 & $<0.001^{* *}$ \\
\hline
\end{tabular}

** Highly significant $p$ value $<0.001$

By LSD for comparison in-between groups (significant $p$.value $<0.05$ )

*significant with control .

\#significant with ischemia.

\$ Significant with Post ischemic IIIa.

(a) Significant with Post ischemic IIIb. 
Table 2: TNF- $\alpha$, HSP-70 and Ghrelin receptor gene expression values expressed as means \pm SD.

\begin{tabular}{|c|c|c|c|c|c|c|}
\hline Groups & Control (I) & Ischemia (II) & Post ischemic IIIa & Post ischemic IIIb & \multirow{2}{*}{$\mathrm{F}$} & \multirow{2}{*}{ P. value } \\
\hline Par & Mean $\pm \mathrm{SD}$ & Mean \pm SD & Mean $\pm \mathrm{SD}$ & Mean \pm SD & & \\
\hline $\mathrm{TNF}-\alpha(\mathrm{Pg} / \mathrm{ml})$ & $18.4 \pm 0.07^{\# \$}$ & $36.5 \pm 2.3^{* \$ @}$ & $20.6 \pm 2^{* \# @}$ & $18 \pm 0.2^{\# \$}$ & 165.52 & $<0.001^{\text {*** }}$ \\
\hline HSP-70 (Pg/mg) & $2.3 \pm 0.4^{\# \$}$ & $12.6 \pm 1.4^{* \$ @}$ & $6.4 \pm 0.4^{* \# @}$ & $2.2 \pm 0.1^{\# \$}$ & 207.469 & $<0.001^{* *}$ \\
\hline Ghrelin receptor gene & $1.73 \pm 0.007^{\# \$}$ & $0.52 \pm 0.01^{* \$ @}$ & $0.74 \pm 0.02^{* \# @}$ & $1.72 \pm 0.02^{\# \$}$ & 8672.475 & $<0.001^{* *}$ \\
\hline
\end{tabular}

** Highly significant $p$.value $<0.001$

By LSD for comparison in-between groups (significant p.value $<0.05$ )

*significant with control.

\#significant with ischemia.

\$ Significant with Post ischemic IIIa.

(a) Significant with Post ischemic IIIb

Table 3: The mean astrocyte number of GFAP, ER $\beta$, and calretinin area $\%$ immunoreaction in the studied groups

\begin{tabular}{|c|c|c|c|c|c|c|}
\hline Groups & Control (I) & Ischemia (II) & Post ischemic IIIa & Post ischemic IIIb & \multirow{2}{*}{$\mathrm{F}$} & \multirow{2}{*}{ P. value } \\
\hline & Mean \pm SD & Mean \pm SD & Mean \pm SD & Mean $\pm \mathrm{SD}$ & & \\
\hline The mean astrocyte number & $0.33 \pm 0.01^{\# \$}$ & $0.63 \pm 0.007^{* \$ @}$ & $0.48 \pm 0.01^{* \# @ ~}$ & $0.32 \pm 0.02^{\text {\#S }}$ & 695.086 & $<0.001^{*}$ \\
\hline Area $\%$ of GFAP & $5.13 \pm 0.007^{\# \$}$ & $9.8 \pm 0.02^{*} @$ & $0.48 \pm 0.01^{* \# @ ~}$ & $5.1 \pm 0.01^{\text {\#\$ }}$ & 101856.927 & $<0.001^{* *}$ \\
\hline Area $\%$ of ER $\beta$ & $145.4 \pm 2.8^{\# \$}$ & $99.2 \pm 1.2^{* @ @ ~}$ & $127.3 \pm 2.1^{* \# @}$ & $144.3 \pm 2.8^{\text {\#\$ }}$ & 422.501 & $<0.001^{* *}$ \\
\hline Area $\%$ of calretinin & $67 \pm 1.4^{\# S}$ & $39 \pm 0.7^{* @ @ ~}$ & $58.2 \pm 0.4^{* \# @}$ & $66.8 \pm 1.1^{\# \$}$ & 887.064 & $<0.001^{* *}$ \\
\hline
\end{tabular}

** Highly significant $P$ value $<0.001$

By LSD for comparison in-between groups (significant $p$.value $<0.05$ )

*significant with control

\#significant with ischemia.

\$ Significant with Post ischemic IIIa.

(a) Significant with Post ischemic IIIb

\section{DISCUSSION}

Acute ischemic stroke (AIS) is one of the major leading causes of death and common causes of adult disability worldwide ${ }^{[47,48]}$. Considering poor prognosis of AIS, it is crucial to develop effective therapies to improve neurological manifestations of its patients. Cerebrolysin, a neuroprotective compound,was tested in several clinical studies with uneven conclusions ${ }^{[19]}$. Therefore, the aim of this study was to examine the efficacy, safety and dosedependent effects of cerebrolysin administration on dentate gyrus of hippocampus in AIS.

Examination of H\&E-stained sections of the ischaemia group showed small dark stained nuclei in the granule cell layer and areas of cell loss. The same results obtained by Cao et al. and Irmak et al. ${ }^{[49,50]}$ who stated that cerebral ischemia increased the expression of transcription factor that plays a pivotal role in mediating inflammatory response and reactive oxygen species (ROS) protein.This overproduction of ROS, inflammation and oxidative stress lead to subsequent neuronal injury and damage ${ }^{[4,50]}$ and increases the occurrence of apoptotic cell death in the brain $^{[51,52]}$. Increase ROS causing release of free calcium that causes deterioration of membrane structure and enzyme activities. Cosequently, nitric oxide radical formation is increased, resulting in cell damage and apoptosis. Cells are characterized by a decrease volume, deterioration in membrane integrity and nuclear fragmentation ${ }^{[53,}{ }^{54]}$. Addionally, the same group showed that the fragmentation index of genomic DNA from brain tissue was significantly higher as compared to control. Similar results were obtained by Liang et al. ${ }^{[3]}$, who noticed that karyopyknosis was evident and the number of neurons was reduced. The ishemic group showed significantly increased MDA with significantly decreased the activity of antioxidant enzymes CAT and GSH when compared to the control group. The same results obtained by Liang et al. ${ }^{[3]}$ who found that cerebral ischemia increased the content of MDA and $\mathrm{NF}-\kappa \mathrm{Bp} 65$; an important transcription factor that plays a pivotal role in mediating inflammatory response and reactive oxygen species (ROS) protein expression.

In the current study, H\&E-stained sections of ishemic group revealed numerous spindle shaped cells in the subgranular zone (SGZ). These finding were explained by Neuberger ${ }^{\text {et al[55] }}$ who stated that hippocampal dentate gyrus is a focus of enhanced neurogenesis and excitability after traumatic brain injury. Increased neurogenesis has been proposed to help repair of the injured granular cells.

Immunohistochemical reaction for ER $\beta$ in sections of the dentate gyrus of the ischemia group showed faint positive reaction in some nuclei of granule cells as compared to the control group. The same results were reported by Altunaet al. and Liet al. ${ }^{[54,56]}$ who added that improvement from ischemia was slower and less complete in animals lacking ER $\alpha$.

As regard calretinin immunoreaction, negative reaction was detected in granule cells of the ischemic group as compared to the control group. Uniform findings were also 
found by Asker et al. ${ }^{[15]}$. Decrease calretinin expression in granule cells as a result of calcium channel dysfunction was found to cause abnormal neuronal excitability ${ }^{[57]}$, impairment in the motor control in mouse cerebellum ${ }^{[58}$, 59]. Also, calretinin immunoreactivity of the Purkinje cells in the treated group was decreased which may be due to the massive degeneration of Purkinje cells, as it was reported that the neuronal degeneration resulted in decrease calretinin expression in the hippocampus and cerebellum ${ }^{[60]}$.

TNF- $\alpha$ and HSP-70 assay showed statistically significant increase in ischemic group. The expression of inflammatory factors was increased in the pathological process of cerebral disease ${ }^{[61]}$. The release of inflammatory molecules, including TNF- $\alpha$, IL- $1 \beta$, IL- $6, \mathrm{NF}-\kappa \mathrm{B}$, and TGF- $\beta$, aggravates cell injury during ischemia stoke ${ }^{[62]}$. This was found to be consistent with previous studies in rat models ${ }^{[63]}$. HSP-70 which is a $70-\mathrm{kDa}$ heat-shock proteins are stress-induced molecules that expressed in response to various types of CNS injuries, including stroke, trauma or neurodegenerative disorders. Marked increase of HSP-70 in brain tissue of ischemic group induced by oxidative stress ${ }^{[64]}$. While, Robinson et al., Zhenget al. and Bienemann et al. ${ }^{[65,66 \& 67]}$ stated that HSP-70 may have antiinflammatory, cytoprotective and anti-apoptotic actions.

Ghrelin, a gastrointestinal peptide with a neuroprotective effects and useful therapeutic role in protecting the brain against injury ${ }^{[17]}$. Ischemic injury of rat brain caused a statistically significant decrease in ghrelin receptor gene. In agreement with our results, it has been found that the expression of ghrelin receptor gene in rat cerebral cortex and spinal cord were obviously decreased by ischemic injury ${ }^{[68,69]}$.

Astrocytes release a variety of trophic factors to influence neuronal survival and plasticity after brain injury ${ }^{[70,71]}$. Reactive astrocytes also overexpress neuropilin-1 and vascular endothelial growth factor to promote angiogenesis after cerebral ischemia ${ }^{[72]}$. These findings suggest that astrocytes may play an important role in functional recovery after stroke $\mathrm{e}^{[73,74,75,76,77]}$.

Immunohistochemically, There was a remarkable increase in the GFAP staining intensity in the ischemic group in comparison with that of control groups, indicating increase the number and prominent processes. Also, these data powered by statistical analysis of GFAP expression and optical density of astrocytes. These findings were confirmedby Nixdorf-Bergewiler et al. ${ }^{[78]}$ who stated that astrocytic response or gliosis was a recognized response to an insult, that typically characterized by an increase in cytoskeletal intermediate filaments which consists of polymerized GFAP. They added thatincrease GFAP expression was the major hallmark of the astroglial response to brain injury.

H\&E- stained sections of the dentate gyrus of group III revealed that some of granule cells regain their normal appearance (with rounded vesicular nuclei), other cells had small dark nuclei.Vaculation of neuropil is still present in small dose(IIIa). These changes are much more improved in high dose of cerebrolysin (IIIb). Small spindle shaped cells were detected in SGZ. Biochemically, the fragmentation index of genomic DNA from brain tissue of post ischemic group was significantly decreased as compared to ishemic group. The same results obtained by Zhang et al[79] who added that cerebrolysin greatly improved neurological outcome when taken after stroke. Also, the same group showed statistically significant decreasing in MDA and significant increase in antioxidant enzymes.

Immunohistochemical results for ER $\beta$ stained sections of group III revealed strong positive nuclear reaction in most granular cells which were more evident with high dose of cerebrolysin (IIIb). Almost identical results were reported by Li et al. ${ }^{[56]}$ that stated ER $\beta$ appear to contribute to early cell proliferation and enhance neurogenesis. Also, in addition to the neuroprotective effect, Cerebrolysin has a capacity to promote brain repair after stroke. Moreover, Cerebrolysin was helpful in ameliorating the neurological outcomes and cerebral blood flow of AIS patients ${ }^{[80,81,25]}$.

Immunohistochemical results for calretinin-stained sections of group III revealed a strong positive expression in granule cells which were more evident with high dose of cerebrolysin (IIIb). The same findings were founded byToledano et al. ${ }^{[82]}$ who explained the increased immunoreactivity of neuronal cells may suggest adaptive mechanisms to fight against the neurodegeneration.

In subgroup III, TNF and $\alpha$ HSP-70 showed significant decreased while Ghrelin receptor gene showed significant increased in expression.The same results obtained byAbdel-Salam et al. ${ }^{[83]}$.

Immunohistochemical results for GFAP-stained sections of group III revealed a strong positive expression of GFAP in astrocytes which were more evident in subgroup IIIb. The same results were obtained by Rockenstein et $a l{ }^{[84]}$ who stated that cerebrolysin has a neurotrophic effects that might reduce the neurodegenerative alterations in Alzheimer's disease (AD). On the other hand, Jin et $a l .{ }^{[85]}$ stated that cerebrolysin did not significantly increase the number of GFAP positive cells, but cerebrolysin dose dependently enhances neurogenesis.

In the current work, stem cells in SGZ are spindle in shape in control group I, increase their number and still spindle in ischemic group II, become large and rounded in post ischemic group III. Neurogenesis occurs in hippocampus, hence undergoes changes throughout the lifespan and is also the most sensitive region of cerebral ischemic injury ${ }^{[86-85]}$. Cerebrolysin augmented neurogenesis in the ischemic brain and improved functional outcomes ${ }^{[87,88 \& 89]}$ It attenuates neuroblast apoptosis and can enhance hippocampal neurogenesis by augmenting survival and proliferation of the hippocampal neural progenitor cells $s^{[00,84]}$. Thus, it plays a major role in promoting neurogenesis and gliogenesis ${ }^{[91,92,93]}$. 


\section{CONCLUSION AND RECOMMENDATION}

Cerebrolysin effectively reversed ischemicinduceddentategyrusinjury ina dose dependantmanner. That is evidenced by the histological, immunohistochemical and biochemical improvement. However, further experimental and clinical studies are required on other CNS regions to clarify the therapeutic roles of cerebrolysin during acute ishemic stroke and its the molecular mechanisms.

\section{CONFLICT OF INTEREST}

There is no potential conflict of interest among the authors.

\author{
ABBREVIATIONS \\ AIS: Acute ischemic stroke \\ TNF- $\alpha$ : tumor necrosis factor- $\alpha$ \\ HSP-70: heat shock protein -70 \\ Gh receptor: Grhelin receptors \\ DNA: deoxyribonucleic acid \\ GFAP: glial fibrillary acidic protein \\ $\operatorname{Er} \beta$ : estrogen receptor beta \\ MDA: Malondialdehyde \\ CAT: Catalase \\ GSH: Reduced glutathione \\ CNS: central nervous system \\ $\mathrm{CA}$ : cornuaammonis \\ FDA: food and drug administration \\ rtPA: recombinant tissue plasminogen activator \\ LP: lipid peroxidation \\ ELISA: Enzyme-Linked-Immuno-Sorbent-Assay \\ ROS: reactive oxygen species \\ SVG: sub-granular zone \\ NSC: neuronal stem cell \\ RGLs: Radial glia-like cells \\ IPCs: intermediate progenitor cells

\section{REFERENCES}

1. Lloyd-Jones D, Adams RJ, Brown TM, Carnethon M, Dai S, De Simone G, Go A. Heart disease and stroke statistics-2010 update. Circulation 2010;121(7): 46-215.

2. Stapf C, Mohr JP. Ischemic stroke therapy. Annu Rev Med. 2002; 53(1):453-475.

3. Liang G, Shi B, Luo W, Yang J. The protective effect of caffeic acid on global cerebral ischemiareperfusion injury in rats. Behav Brain Funct. 2015; 11(1): 1-18.
4. Pandya RS, Mao L, Zhou, Zhou S, Zeng J, John Popp, A, Wang, X. Central nervous system agents for ischemic stroke: neuroprotection mechanisms. Cent Nerv Syst Agents Med Chem. 2011; 11(2):81-97.

5. Zhao Y, Gu JH, Dai CL, Liu Q, Iqbal K, Liu F, Gong CX. Chronic cerebral hypoperfusion causes decrease of O-GlcNAcylation, hyperphosphorylation of tau and behavioral deficits in mice. Front. Aging Neurosci.2014; 6:10.

6. Pradeep H, Diya JB, Shashikumar S, Rajanikant GK. Oxidative stress-assassin behind the ischemic stroke. Folia Neuropathol 2012; 50(3):219-230.

7. Moro MA, Almeida A, Bolaños JP, Lizasoain I. Mitochondrial respiratory chain and free radical generation in stroke. Free Radic Biol Med 2005; 39(10): 1291-1304

8. Leonard MO, Kieran NE, Howell K, Burne MJ, Varadarajan R, Dhakshinamoorthy $\mathrm{S}$, Leonard, MO. Reoxygenation-specific activation of the antioxidant transcription factor $\mathrm{Nrf} 2$ mediates cytoprotective gene expression in ischemia-reperfusion injury. FASEB J 2006; 20(14):2624-2626.

9. Pettigrew LC, Kryscio RJ, Norris CM. The TNF $\alpha$ transgenic rat: hippocampal synaptic integrity, cognition, function, and post-ischemic cell loss. PloS One 2016; 11(5): e0154721.

10. Gonçalves JT, Schafer ST, Gage FH.Adult neurogenesis in the hippocampus: from stem cells to behavior. Cell, 2016; 167(4): 897-914.

11. Woitke F, Ceanga M, Rudolph M, Niv F, Witte OW, Redecker C, Kunze A, Keiner S. Adult hippocampal neurogenesis poststroke: More new granule cells but aberrant morphology and impaired spatial memory. PloS one, 2017; 12(9): 0183463.

12. Berg DA, Bond AM, Ming GL, Song H. Radial glial cells in the adult dentate gyrus: what are they and where do they come from?. F1000Research, 2018; 7 .

13. Whitman MC, GreerCA.Adultneurogenesis and the olfactory system. Progress in neurobiology,2009; 89(2): 162-175.

14. Liu F, Day M, Muniz LC, Bitran D, Arias R, Revilla-Sanchez R, Grauer S, Zhang G, Kelley C, Pulito V, Sung A.Activation of estrogen receptor- $\beta$ regulates hippocampal synaptic plasticity and improves memory. Nature neuroscience,2008; 11(3): 334.

15. Asker SA, Mazroa SA, SabriY.Histological and immunohistochemical implications of kitamine protracted doses as a novel candidate 
in antidepressant treatment adult rat cerebellar cortex.Int JAdv Res 2016; 4 (6):39-50

16. Turner CP, Debenedetto D, Liu C. NMDAR blockade-induced neonatal brain injury: Reversal by the calcium channel agonist BayK 8644 . NeurosciLett.2009; 450:292-295.

17. Spencer SJ, Miller AA, Andrews ZB. The role of ghrelin in neuroprotection after ischemic brain injury. Brain Sci 2013; 3(1):344-359.

18. Shcherbak NS, Galagudza MM, Kuzmenkov AN, Ovchinnikov DA, Mitrofanova, LB, Barantsevich ER, Shlyakhto EV.A new rat model of reversible global cerebral ischemia. Bull Exp Biol Med 2012; 152(5):656-8.

19. Zhang L, Zhang RL, Jiang Q, Ding G, Chopp M, Zhang ZG. Focal embolic cerebral ischemia in the rat. Nat proto 2015; 10(4):539-547.

20. Zhang D, Dong Y, Li Y, Chen J, Wang J, Hou L. Efficacy and safety of Cerebrolysin for acute ischemic stroke: a meta-analysis of randomized controlled trials. BioMed Res Int 2017; 2017:1-10.

21. Cuevas $\square$ Olguin R, Roychowdhury S, Banerjee A, Garcia $\square$ Oscos F, Esquivel $\square$ Rendon E, Bringas ME, Kilgard MP, Flores G, Atzori M. Cerebrolysin prevents deficits in social behavior, repetitive conduct, and synaptic inhibition in a rat model of autism. J Neurosci Res 2017; 95(12):2456-2468

22. Crews L, Masliah E. Molecular mechanisms of neurodegeneration in Alzheimer's disease. Hum Mol Genet 2010; 19(R1):R12-R20.

23. Poon W, Vos P, Muresanu D, Vester J, Von Wild K, Hömberg V, Wang E, Lee TM, Matula C. Cerebrolysin Asian Pacific trial in acute brain injury and neurorecovery: design and methods. J Neurotrauma 2015; 32(8):571-580.

24. Zurita E, Huerta M, De Jesús L, De La Cruz F, Ortiz-Butron R,Ortiz-Butron R, Flores G, GómezVillalobos MDJ. Cerebrolysin effects on cardiac neuropathy in diabetic rats. PharmacolPharma 2017; 8(07):215-230.

25. Zhang L, Chopp M, Lu M, Zhang T, Winter S, Doppler E, Doppler E, Gang Zhang Z. Cerebrolysin dose-dependently improves neurological outcome in rats after acute stroke: A prospective, randomized, blinded, and placebo-controlled study. Int J Stroke 2016; 11(3):347-355.

26. Heiss WD, Brainin M, Bornstein NM, Tuomilehto J, Hong Z. Cerebrolysin in patients with acute ischemic stroke in Asia: results of a double-blind, placebo-controlled randomized trial. Stroke 2012; 43(3):630-636.

27. Gawish M, Azmy A, Abdallah M. Effect of protein malnutrition on the liver of prepubertal male albino rats (light and electron microscope study). Z U M J 2006; Special edition pp: 111-133

28. Carvalho CAMD, Tirapelli DPDC, Rodrigues AR, LizarteNeto FS, Novais PC, Silva, JP, Tirapelli LF. Morphological and immunohistochemical analysis of apoptosis in the cerebellum of rats subjected to focal cerebral ischemia with or without alcoholism model. Acta Cir Bras 2016; 31(9):629-637.

29. Al-Bazii WJ. Estimation of some oxidative stress parameters in the serum and cerebellum of ovariectomized rats. J KerbalaUniv 2014; 12:8794.

30. Kasahara J, Uchida H, Tezuka K, Oka N. Postischemic Anhedonia Associated with Neurodegenerative Changes in the Hippocampal Dentate Gyrus of Rats. Neural Plast 2016; 2016:120 .

31. Pourmemar E, Majdi A, Haramshahi M, Talebi M, Karimi P, Sadigh-Eteghad S. Intranasal cerebrolysin attenuates learning and memory impairments in D-galactose-induced senescence in mice. ExpGerontol 2017; 87:16-22.

32. Gage GJ, KipkeDR, Shain W. Whole animal perfusion fixation for rodents. J Vis Exp 2012; (65):1-9.

33. Aksoy M, Ahiskalioglu A, Ince I, Celik M, Dostbil A,Kuyrukluyildiz U, Suleyman H. The relation between the effect of a subhypnotic dose of thiopental on claw pain threshold in rats and adrenalin, noradrenalin and dopamine levels. Exp Anim 2015; 64 (4): 391-396.

34. Vonsattel JPG, Del Amaya MP, Keller CE. Twentyfirst century brain banking. Processing brains for research: the Columbia University methods. Acta neuropathol 2008; 115(5):509-532.

35. Bancroft $\mathrm{J}$ and Layton C:Theory and Practice of histological techniques. 7th ed.Churchill Livingstone of El Sevier, Philadelphia (2013) pp: 172-214.

36. Vasic R, Stojiljkovic M, Milenkovic I, Pekovic S, Rakic L. Immunoreactivity of glial fibrillary acidic protein in cortex and hippocampus after neonatal sensorimotor cortex lesion. Iugoslav Physiol Phamacol Acta 1998; 37(1):237-245.

37. Ramos-Vara, José GA, Kiupel M, Baszler T, Bliven L, Brodersen B, Brodersen, B, Chelack, B, CzubS, Del PieroF, Dial S, Ehrhart EJ, Graham T, Manning L, Paulsen D, Valli VE, West K. Suggested guidelines for immunohistochemical techniques in veterinary diagnostic laboratories. J Vet Diagn Invest 2008; 20(4):393-413.

38. Rabuffetti, M, Sciorati, C, Tarozzo, G, Clementi, 
E, Manfredi, A A, Beltramo, M. Inhibition of caspase-1-like activity by Ac-Tyr-ValAla-Asp-chloromethyl ketone induces longlasting neuroprotection in cerebral ischemia through apoptosis reduction and decrease of proinflammatory cytokines. J Neurosci 2000; 20(12):4398-4404.

39. Ohkawa H, Ohishi N, Yagi K. Assay of lipid peroxides in animal tissues by thiobarbituric acid reaction. Anal Biochem 1979; 95:351-358.

40. Marklund SL. Pyrogall of autooxedation. In: Greenwald RA (ed), Handbook of Methods for Oxygen Radical Research. CRC Press, Boca Raton, Florida,1985; pp243-247

41. Clairborne A. Catalase activity. In: Greenwald RA (ed.) Handbook of Methods for Oxygen Radical Research. CRC Press, Boca Raton, Florida, 1985; pp283-284.

42. Ellman GL. Tissue sulfhydryl groups. Arch. Biochem Biophys 1959; 82(1):70-77.

43. 43-Shen SQ, Zhang Y, Xiang JJ, Xiong CL. Protective effect of curcumin against liver warm ischemia/reperfusion injury in rat model is associated with regulation of heat shock protein and antioxidant enzymes. World J Gastroenterol 2007; 13(13):1953.

44. Brinkhof B, Spee B, Rothuizen J, Penning LC. Development and evaluation of canine reference genes for accurate quantification of gene expression. Anal Biochem 2006; 356(1):36-43.

45. Baessler, A, Hasinoff, MJ, Fischer,M, Reinhard, W, Sonnenberg, GE, Olivier, M, Erdmann, J, Schunkert, H, Doering, A, Jacob, HJ, Comuzzie, AG. Genetic linkage and association of the growth hormone secretagogue receptor (ghrelin receptor) gene in human obesity. Diabetes 2005; 54(1):259267.

46. Pandey SA, ChandnaSAn improved nonenzymatic "DNA ladder assay" for more sensitive and early detection of apoptosis." Cytotechnology 2012; 64(1) 9-14.

47. Murray CJ, Vos T, Lozano R, Naghavi M, Flaxman A D, Michaud C, Ezzati M, Shibuya K, Salomon JA, Abdalla S, Aboyans V. Disability-adjusted life years (DALYs) for 291 diseases and injuries in 21 regions, 1990-2010: a systematic analysis for the global burden of disease study. Lancet 2012; 380 (9859):2197-2223.

48. Murray CJL, Lopez AD. Measuring the global burden of disease. New England J Med 2013; 369(5):448-457.

49. Cao W, Carney JM, Duchon A, Floyd RA, Chevion M. Oxygen free radicals involvement in ischemia and reperfusion injury to brain. NeurosciLett 1998; 88: $233-8$.

50. Irmak MK, Fadillioglu E, Sogut S, Erdoqan H, Gulec M, Ozer M. Effects of caffeic acid phenethyl ester and alpha-tocopherol on reperfusion injury in rat brain.Cell BiochemFunct 2003; 21:283-9.

51. Chan PH. Reactive oxygen radicals in signaling and damage in the ischemic brain. J Cereb Blood Flow Metab 2001; 21:2-14.

52. Choi-Kwon S, Park KA, Lee HJ, Park MS, Lee JH, Jeon, SE, Choe MA, Park KC. Temporal changes in cerebral antioxidant enzyme activities after ischemia and reperfusion in a rat focal brain ischemia model: effect of dietary fish oil. Dev Brain Res 2004; 152(1): 11-18.

53. Vejux A, Lizard G. Cytotoxic effects of oxysterols associated with human diseases: Induction of cell death (apoptosis and/or oncosis), oxidative and inflammatory activities, and phospholipidosis. Mol Aspects Med 2009; 30(3):153-170

54. Altuna G, Kaplana S, Deniza OG, Kocacanb SE, Cananc S, Davisd D, Marangozf C. Protective effects of melatonin and omega- 3 on the hippocampus and the cerebellum of adult Wistar albino rats exposed to electromagnetic fields. J Microsco. Ultrastructure 2017; 5:230-241.

55. Neuberger EJ, Swietek B, Corrubia, L, Prasanna A, Santhakumar, V. Enhanced dentate neurogenesis after brain injury undermines long-term neurogenic potential and promotes seizure susceptibility. Stem cell reports 2017, 9(3):972-984.

56. Li J, Siegel M, Yuan M, Zeng Z, Finnucan L, Persky R, Hurn PD, McCullough LD. Estrogen enhances neurogenesis and behavioral recovery after stroke. J Cereb Blood Flow Metab 2011; 31(2):413-425.

57. Cochran SM, Kennedy M, McKerchar CE, Steward LJ, Pratt JA, Morris BJ. Induction of metabolic hypofunction and neurochemical deficits after chronic intermittent exposure to phencyclidine: differential modulation by antipsychotic drugs. Neuropsychopharmacol 2003; 28:265-275.

58. Schiffmann SN, Cheron G, Lohof A, d'Alcantara P, Meyer M, Parmentier M, Schurmans S. Impaired motor coordination and Purkinje cell excitability in mice lacking calretinin. ProNatiAcadSci 1999; 96(9):5257-5262.

59. Barinka F, Druga R. Calretinin expression in the mammalian neocortex: a review. Physiolo Res 2010; 59(5):665-677.

60. Byun K, Kim D, Bayarsaikhan E, Kim J, Oh J, Kwak G, Jeong GB, Jo, SM, Lee B. Changes of calcium binding proteins, $\mathrm{cFos}$ and $\mathrm{COX}$ in hippocampal formation and cerebellum of 
Niemann- Pick, type C mouse," J. Chem. rmation and cerebellum of Niemann- Pick, type C mouse," J ChemNeuroanat 2013; 52:1-8.

61. Gilmore TD. Introduction to NF- $\kappa \mathrm{B}$ : players, pathways, perspectives. Oncogene 2006; 25(51):6680-6684.

62. Jin R, Liu L, Zhang S, Nanda A, Li G. Role of inflammation and its mediators in acute ischemic stroke. J Cardiovascular Translational Res 2013; 6(5): 834-851.

63. Yasuda Y, Shimoda T, Uno K, Tateishi N, Furuya S,Tsuchihashi Y, Fujita S. Temporal and sequential changes of glial cells and cytokine expression during neuronal degeneration after transient global ischemia in rats. J Neuroinflammation 2011; 8(1): 70 .

64. Turturici G, Sconzo G, Geraci F. Hsp70 and its molecular role in nervous system diseases. Biochem Res Int 2011; 2011:1-18.

65. Robinson MB, Tidwell JL, Gould T, Taylor AR, Newbern JM, Graves J, Milligan, CE. Extracellular heat shock protein 70: a critical component for motor neuron survival. J Neurosci 2005; 25(42):9735-9745.

66. Zheng Z, Kim JY, Ma H, Lee JE, Yenari MA. Antiinflammatory effects of the $70 \mathrm{kDa}$ heat shock protein in experimental stroke. J Cereb Blood Flow Metabo 2008; 28(1):53-63.

67. Bienemann AS, Lee YB, Howarth J, Uney JB. Hsp70 suppresses apoptosis in sympathetic neurones by preventing the activation of c-Jun. J Neurochem 2008; 104(1):271-278.

68. Miao Y, Xia Q, Hou Z,Zheng Y, Pan H, Zhu S. Ghrelin protects cortical neuron against focal ischemia/reperfusion in rats. Biochem Biophys Res Commun 2007; 359(3):795-800.

69. Zhang Q, Huang C, Meng B, Tang T, Shi Q, Yang, $\mathrm{H}$. Acute effect of ghrelin on ischemia/reperfusion injury in the rat spinal cord. Int J Mol Sci 2012; 13(8):9864-9876.

70. Hatten M, Liem R, Shelanski M, Mason C. Astroglia in central nervous injury.Glia 1991; 4:233-243.

71. Takano T, Oberheim NA, Cotrina ML, Nedergaard M. Astrocytes and ischemic injury.Stroke 2009; 40(3):8-12.

72. Hirayama Y, Ikeda-Matsuo Y, Notomi S, Enaida H, Kinouchi H. Astrocyte-mediated ischemic tolerance.J Neurosci 2015; 35(9):3794-805.

73. Rid JL, Malhotra SK, Privat A, Gage FH. Reactive astrocytes: cellular and molecular cues to biological function. Trends Neurosci 1997; 20:570-577.
74. Tokita $\mathrm{Y}$, Keino H, Matsui F,Aono S, Ishiguro H,Higashiyama S,Oohira A. Regulation of neuregulin expression in the injured rat brain and cultured astrocytes. J Neurosci 2001; 21:1257-1264.

75. Zhang Z, Chopp M. Vascular endothelial growth factor and angiopoietins in focal cerebral ischemia Trends Cardiovasc Med 2002; 12:62-66.

76. Song H, Stevens CF, Gage FH. Astroglia induce neurogenesis from adult neural stem cells. Nature 2002; 417:39-44.

77. Chen Y, Swanson RA. Astrocytes and brain injury.J Cereb Blood Flow Metab 2003; 23:137-149.

78. Nixdorf-Bergewiler BE, Albrecht D, Heinemann $\mathrm{U}$. Developmental changes in the number, size and orientation of GFAP-positive cells in CA1 region of rat hippocampus. Glia 1994; 12:180-195.

79. Zhang C, Chopp M, Cui Y,Wang L, Zhang R, Zhang L, Lu M, Szalad A, Doppler E, Hitzl M, Zhang ZG. Cerebrolysinenhances neurogenesis in the ischemic brain and improves functional outcome after stroke. J Neurosci Res 2010; 88 (15):3275-3281

80. Zhang C, Chopp M, Cui Y,Wang L, Zhang R, Zhang L, Lu M, Szalad A, Doppler E, Hitzl M, Zhang ZG. Cerebrolysinenhances neurogenesis in the ischemic brain and improves functional outcome after stroke. J Neurosci Res 2010; 88 (15):3275-3281

81. Abdel-Salam OM, Mohammed NA, Youness ER, Khadrawy YA, Omara EA, Sleem, AA.Cerebrolysin protects against rotenone-induced oxidative stress and neurodegeneration. J Neurorestoratol 2014; 2:47-63

82. Toledano A,AlvarezMI, Monleón E, ToledanoDíaz A, Badiola JJ,Monzón, M. Changes induced by natural scrapie in the calretinin-immunopositive cells and fibres of the sheep cerebellar cortex. Cerebellum 2012; 11(2):593-604.

83. Abdel-Salam OM, Mohammed NA, Youness ER, Khadrawy YA, Omara EA, Sleem, AA.Cerebrolysin protects against rotenone-induced oxidative stress and neurodegeneration. J Neurorestoratol 2014; 2:47-63.

84. Rockenstein E, Mante M, Adame A, Crews L, Moessler H,Masliah, E. Effects of cerebrolysin on neurogenesis in an APP transgenic model of alzheimer's disease.Acta Neuropathol 2007, 113:265-275.

85. Jin R, Liu L, Zhang S, Nanda A, Li G. Role of inflammation and its mediators in acute ischemic stroke. J Cardiovascular Translational Res 2013; 6(5): 834-851. 
86. Cui Y, Liu X, Li X, Yang H. In-Depth proteomic analysis of the hippocampus in a rat model after cerebral ischaemic injury and repair by danhong Injection (DHI). Int J Mol Sci 2017; 18(7):1-22.

87. Jin K, Minami M, Lan JQ, Mao XO, Batteur S,Simon RP, Greenberg DA. Neurogenesis in dentate subgranular zone and rostral subventricularzone after focal cerebral ischemia in the rat. Proc Natl Acad Sci 2001; 98:4710-4715.

88. Zhang RL, Zhang ZG, Zhang L, Chopp M. Proliferation and differentiation of progenitor cells in the cortex and the subventricular zone in the adult rat after focal cerebral ischemia. Neurosci 2001; 105:33-41.

89. Arvidsson A, Collin T,Kirik D, Kokaia Z, Lindvall O. Neuronal replacement from endogenous precursors in the adult brain after stroke. Nat Med 2002; 8:963-970.
90. Tatebayashi Y, Lee MH, Li L, Iqba $1 \mathrm{~K}$, GrundkeIqbal I. The dentate gyrus neurogenesis: a therapeutic target for Alzheimer's disease. Acta Neuropathol 2003; 105:225-232.

91. Chen H, Tung YC, Li B, Iqba 1K, Grundke-Iqbal I. Trophic factors counteract elevated FGF-2-induced inhibition of adult neurogenesis. Neurobiol Aging 2007; 28:1148-1162.

92. Nagao M, Sugimori M, Nakafuku M. Cross talk between notchand growth factor/cytokine signaling pathways in neural stem cells. Mol Cell Biol 2007; 27: 3982-3994.

93. Ren J, Sietsma D, Qiu S, Moessler H, Finklestein SP. Cerebrolysin enhances functional recovery following focal cerebral infarction in rats. Restor Neurol Neurosci 2007; 25:25-31. 
الملخص العربى

\section{فعالية سريبروليسين على بنية التثفيف المسنن من الحصين بعد السكتة الدماغية}

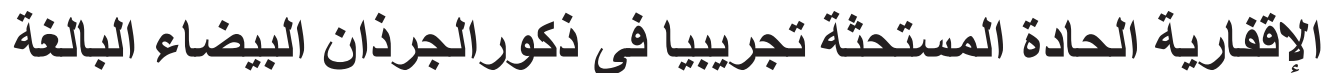

\section{(دراسه هستولوجيه وهستوكيميائيه مناعيه وبيوكيميائيه)}

هبه محمد عبد العزيز وسماح محمد أحمد ومها زايد محمد حسن' وهاتم مجدي عبد النورج"

'قشم الههتولوجيا وبيولوجيا الخلية ـ كلية الطب - جامعه الزقازيق

بقسم الكيمياء الحيوية ـ كلية الطب - جامعه الزقازيق

الخلفية: السكتةالإقفاريةالحادةهياضطر ابطبي بالمخهيتميزبضعف تدفق الدمالمفاجئ إلى منطقة من الدماغهمما يؤدي إلى فقدان وظيفتها العصبية.يعتبر سرييروليسين دواء للتغذية العصبية ، فهوخلبط من البيتيدات العصبية والأحماض مئي

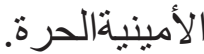

هدف الدراسة: تهدف هذه الدر اسةإلى تقييم دورسيريبروليسين هستولوجيا وهستو كيميائي مناعيو بيوكيميائيه في السكتة الدماغية الإقفارية الحادة في ذكور الجرذان البيضاء البالغة وأيضا تقيم تأثير هاالمعتمدعلى الجر عة. المو اد و الطرق: استخدم ثلاثون من ذكور الجرذان البيضاءالبالغة، قسمو الي ثناث مجموعات متساوية: المجموعة الضابطة ومجمو عةنقصتروية أو الاقفارومجموعة ما بعد الاقفار.قسمت المجموعة الثالثة إلى مجموعتين فرعيتين: مجموعة فرعية أولي حيث عولجت الجرذان بسرييروليسين 2.5 ملجم / كج ،في حين عولجت جرذان المجموعة الفرعية الثانية بسرييروليسين5 ملجم / كجم. صبغت مقاطع المخ بصبغة الهيماتوكسيلين و الأيوسين و استخدمت أيضا صبغة هستوكيميائية مناعية لبروتين GFAP، ومستقبلات الاستروجين بيتاو calretinin.ثم سجلت النتائج وحللت إحصائيا وتم أيضا قياس وتسجيل معاملات الإجهاد التأكسديو $\alpha$ و TNF النتائج: أظهرالفحص المجهرى لمقاطع التلفيف الحصينى المسنن المصبوغة بصبغة الهيماتوكسيلين والأيوسين للمجموعة الثانية وجود أنوية صغيرة وداكنة اللون و مناطق فقدت بها الخلايا ،كما وجدت العديد من الخلايا على شكل مغزل في منطقة شبه الحبييية. أظهر التفاعل الهستوكيميائي المناعي لبروتينGFAP زيادة التعبير المناعي في سيتوبلازم الخلايا النجمية ، وتفاعل مناعي إيجابي خافت لـ ER في نوى الخلايا الحبييية و تم الكثف عن تفاعلات قوية في سيتوبلازمالخلايا النجمية و تفاعل سلبي لcalretinin في الخلايا العصبية و انخفضت الإنزيمات المضادة للأكسدة في أنسجة المخ وكانت TNF $\alpha$ و MDA و 1 و HSP-70 مرتفعة .في المجمو عة الإقفارية مقارنة بالمجموعة الضابطة ومجمو عات ما بعد المعالجة الإقفارية، كماز اد بشكل ملحوظ مؤشر تجزئة الحمض النووي. وأظهرت النتائج أن العلاج بسريبروليسين 2.5 ملغم / كغ قد أعطي تحسنا جزئيا ، في حين أن 5 ملغم / كغم منها أحدث تأثير ا أفضل. الخلاصة: نستخلص من هذه الدراسة أن عقار سريبروليسين كان فعالا فى علاج السكتةالإقفارية الدماغيةالحادة المستحثة تجريبيا فى ذكور الجرذان البيضاءبطريقة توافقت مع زيادة الجرعة و ظهر ذلك فى تحسن البنيةالنسيجية و النسيجية الكيميائية المناعية للتلفيف المسنن للحصين و كذلك تحسنت النتائج البيوكميائيه. 